\title{
SECONDARY METABOLISMIN IN ANNONACEAE: POTENCIAL SOURCE OF DRUGS ${ }^{1}$
}

\author{
MARIANO MARTÍNEZ-VÁZQUEZ² \& ROSA ESTRADA-REYES³
}

\begin{abstract}
Several species of Annona (Annonaceae) are used in traditional Mexican medicine by their anti-anxiety, anticonvulsant and tranquilizing properties. It has been reported that the alkaloids isolated from some species of the Annona have affinity to serotonergic 5-HT1A receptors and modulate dopaminergic transmission, which is involved in depressive disorders. In this review it is showed the results of the antidepressant-like effect of an alkaloid extract from the aerial parts of Annona cherimola (TA) in mice. The antidepressant-like effect was evaluated in the forced swimming test. To elucidate a possible mechanism of action, experiments of synergism with antidepressant drugs, such as imipramine (IMI), clomipramine (CLIMI), and fluoxetine (FLX), were carried out. The neurotransmitter content (DA: dopamine, 5HT: serotonin and its metabolites, HVA: homovanillic acid and 5HIAA:5-hydroxyindoleacetic) in the whole brain of mice were also determined by HPLC method. The results showed that repeated treatment with TA produced antidepressant-like effects in mice. This effect was not related to an increase in locomotor activity. Administration of TA facilitated the antidepressant effect of IMI and CLIMI as well as increased the turnover of DA and 5-HT. The alkaloids: 1,2-dimethoxy-5, 6.6 to 7-tetrahydro-4H-dibenzoquinoline-3,8,9,10-tetraol, anonaine, liriodenine, and nornuciferine were the main constituents of TA.
\end{abstract}

Index terms: antidepressant, alkaloids, Annona sp..

\section{METABOLISMO SECUNDÁRIO EM ANNONACEA: FONTE POTENCIAL DE DROGAS}

RESUMO - Várias espécies de Anona (Annonaceae) são utilizadas na medicina tradicional mexicana por seu antiansiedade anticonvulsiva e propriedades tranquilizantes. Tem sido relatado que os alcaloides isolados a partir de algumas espécies de Anona têm afinidade para receptores serotoninérgicos 5-HT1A e modular à transmissão dopaminérgica, que está envolvida em distúrbios depressivos.Nesta revisão, mostraram-se os resultados do efeito antidepressivo do extrato alcaloide das partes aéreas de Anona cherimólia (TA) em camundongos. $\mathrm{O}$ efeito antidepressivo foi avaliado no teste de natação forçada. Para elucidar um possível mecanismo de ação, as experiências de sinergismo com drogas antidepressivas, tais como a imipramina (IMI), clomipramina (CLIMI) e fluoxetina (FLX), foram realizadas. O teor de neurotransmissor (DA: serotonina e dos seus metabólitos, HVA:: dopamina, 5HT ácido homovanílico e 5HIAA :5-hidroxiindoleacético) em todo o cérebro de ratinhos foi também determinado pelo método de HPLC.Os resultados mostraram que o tratamento repetido com ácido tartárico produzido com antidepressivo provocou efeitos semelhantes em ratinhos. Este efeito não foi relacionado a um aumento da atividade locomotora. Administração da TA facilitou o efeito antidepressivo do IMI e CLIMI bem como o aumento do volume de negócios de DA e 5-HT. Os alcaloides de: 1,2-dimetoxi-5, 6,6 a, 7-tetrahydro-4H-dibenzoquinoline-3,8,9,10-tetraol, anonaine, liriodenina, e nornuciferine foram os principais constituintes da TA.

Termos para indexação: antidepressivo, alcalóides, Annona sp..

\footnotetext{
${ }^{1}$ Palestra Anonáceas - V Congresso Internacional \& Encontro Brasileiro sobre Annonaceae: do gene à exportação (19 a 23 de Agosto de 2013). Botucatu-SP.

${ }^{2}$ Instituto de Química, Universidad Nacional Autónoma de México. C. Exterior, C. Universitaria, Coyoacán 04510, México, D. F., México. ${ }^{3}$ Instituto Nacional de Psiquiatría "Ramón de la Fuente Muñiz", Calzada México-Xochimilco 101, Col. San Lorenzo Huipulco, Delegación Tlalpan, México City 14370, México.
} 


\section{INTRODUCTION}

Mental depression is a chronic illness that significantly affects a person's moods, behavior and general health. According to World Health Organization's prediction, depression will become the second most common disease by the year 2020 . At present, there are several classes of classical antidepressants in clinical practice, including tricycle antidepressants (TCAS), monoamine oxidase inhibitors (MAOIs), selective serotonin reuptake inhibitors (SSRIs), noradrenergic reuptake inhibitors (NARIs) and specific serotonin-noradrenalin reuptake inhibitors (SNRTs). However, most of these drugs are undesirable, due to their side effects and efficacy for only a certain proportion of patients. Thus, there is an unmet need for safe, well-tolerated and powerful antidepressants. The need for the discovery and development of new pharmaceuticals for the treatment of depression demands that all approaches to drug discovery be exploited.

The traditional herbal medicines and their preparations have been used widely for thousands of years in many countries, such as in China, Korea, Japan, etc. In recent years, much attention has been paid towards the exploration of herbal preparations for application in mental diseases including depression and other disorders (CUI YIN et al., 2011).

The 5-HT1A receptors have been implicated in depressive disorders and in the effect of antidepressant drugs (BLIER and MONTIGNY, 1994; MARTINEZ-MOTA et al., 2002; BLIER and WARD, 2003). Furthermore, dopamine mediates the antidepressant effect of tricyclic antidepressants in the forced swimming test (FST) (CERVO and SAMANIN, 1987).

\section{Annona cherimolia as source of potential anti-depressive agents}

It is well known that the Annonaceae family is rich in alkaloids (LEBOEUF et al., 1982). Previous studies have shown that alkaloids isolated from species of the Annona genus possess an affinity for the 5-HT1A receptors in vitro and participate in dopamine biosynthesis (PROTAIS et al., 1995; HASRAT et al., 1997a, b; LEE et al., 2008). Thus, it has been proposed that alkaloids derived from the Annona could induce antidepressant-like effects.

Experiments with animal models have confirmed the anxiolytic-like and anticonvulsant activities of the polar and hexane extracts of Annona diversifolia, Annona muricata and Annona cherimolia (GOUEMO et al., 1997; HASRAT et al., 1997a; GONZALEZ-TRUJANO et al., 2001). Furthermore several species of Annona (Annonaceae) are used in traditional Mexican medicine due to their anti-anxiety, anticonvulsant, and tranquilizing properties (TORTORIELLO and ROMERO, 1992; GUPTA,1995).

It was previously reported the anxiolytic-like effect of a hexane extract of Annona cherimolia in mice, on the same way it was described the toxicity of methanol extract of this specie (LOPEZRUBALCAVA et al., 2006).

In a preliminary experiment it was evaluated the anti-depressive activity in the forced swimming test (FST) of an alkaloid extract (TA) from the aerial parts of A. cherimolia. In the FST an increase of immobility time reflect a depressive-like conduct in mice. The results shown in table 1 demonstrated that a single administration of TA at 5,10 and $15 \mathrm{mg} / \mathrm{Kg}$ doses was not active; a similar result was showed by fluoxetine at 10 and $15 \mathrm{mg} / \mathrm{Kg}$ doses. By contrasting the anti-depressive drugs imipramine (IMI) at 12.5, 25 and $32 \mathrm{mg} / \mathrm{Kg}$ doses and clomipramine (CLM) at $12.5,25$ and $50 \mathrm{mg} / \mathrm{Kg}$ were active.

In a subsequent experiment it was evaluated the effect of the combined administration of suboptimal doses of TA (5 and $10 \mathrm{mg} / \mathrm{kg}$ ) with subthreshold doses of IMI $(12.5 \mathrm{mg} / \mathrm{kg})$, CLIMI $(12.5$ $\mathrm{mg} / \mathrm{kg})$ and FLX $(10$ and $15 \mathrm{mg} / \mathrm{kg})$. The combination of TA at 5 and $10 \mathrm{mg} / \mathrm{kg}$ facilitated the antidepressant effect of a suboptimal dose of CLIMI $(12.5 \mathrm{mg} / \mathrm{kg})$, producing a reduction of immobility time of $29.6 \%$ and $46.8 \%(H=15.83, d f=2, p \leq 0.001)$, respectively, whereas TA at $10 \mathrm{mg} / \mathrm{kg}$ in combination with IMI $(12.5 \mathrm{mg} / \mathrm{kg}, \mathrm{H}=18.26, \mathrm{df}=2, \mathrm{p} \leq 0.001)$ produced a statistically significant reduction $(58.73 \%)$ in the immobility time (Table 2). These results suggest that TA enhanced the effects of IMI and CLIMI. In contrast, the combined administration of TA ( 5 and $10 \mathrm{mg} / \mathrm{kg}$ ) and FLX (10 and $15 \mathrm{mg} / \mathrm{kg}$ ) produced an insignificant decrease $(23.63 \%)$ in the immobility time at the highest doses of both compounds $(\mathrm{H}=$ $5.63, \mathrm{df}=4, \mathrm{p}=0.072$ ). None of the combinations tested in the FST produced significant changes in the locomotor activity test.

The alkaloids: 1,2-dimethoxy-5, 6.6 to, 7-tetrahydro-4H-dibenzoquinoline-3,8,9,10-tetraol (1), anonaine (2), liriodenine (3), and nornuciferine (4) were the main constituents of AE (MARTINEZVAZQUEZ, 2012).

The results showed in the neurochemical evaluation indicate that the repeated administration of TA at $10 \mathrm{mg} / \mathrm{kg}$ produced a generalized increase in the serotonin (5-hydroxytryptamine, 5-TH) and dopamine (DA) turnover in the whole brain of mice, 
through both an increase in the concentration of the neurotransmitters and their metabolism. Considering the behavioral actions of this treatment it is possible to suggest that the antidepressant-like actions of TA (at a repeated treatment) are mediated by a mechanism in which participate monoamines oxidases. In agreement with the neurochemical data, the effects of TA are similar to those induced by IMI and CLIMI in virtue of producing an increase in the serotonergic turnover, but different on the dopaminergic system, in which both antidepressant drugs induced a reduction in the DA turnover. Previous information of in vitro studies suggest that the alkaloids derived from Annona's species participate in both DA synthesis and dopaminergic neurotransmission (PROTAIS et al., 1995; LEE et al., 2008), and some of them have been proposed as agonist of serotonergic receptors that participate in depression (HASRAT et al., 1997a,b). Thus this is the first study that relates the antidepressant effects of TA with an enhancement of the DA and 5-HT neurotransmission. Several data of our study may suggest that the serotonergic system have secondary participation in the actions of TA in the FST since: (a) TA did not synergize with the serotonin selective reuptake inhibitor, FLX, to enhance their antidepressant-like actions in mice; (b) TA increases the turnover rate of 5-HT in contrast with FLX, which induces a reduction in the turnover rate of 5-HT in the whole brain of mice.

Although both behavioral and neurochemical evaluations point towards a mechanism of action mediated by monoamines, it cannot be ruled out, the mediation of other neurotransmitter systems in the antidepressant-like effect of TA.

Additionally tetrahydroisoquinolines (THIQs), the most numerous naturally occurring alkaloids, include 1-benzyl-THIQs and aporphines such 1-4 which have structural similarities to dopamine could interact with dopamine receptor (DR).

This proposal has been supported by the fact that recently several studies have proved that some isoquinoline alkaloids have affinity for D2 receptors. The D2-like DR antagonists are used in the treatment of schizophrenia and the agonists are utilized to treat Parkinson's disease. (BERENGUER et al., 2009)

Apomorphine is a morphine decomposition product produced by boiling it with concentrated acid. This alkaloid possesses an aporphine skeleton and is a non-selective dopamine agonist which activates both $\mathrm{D}_{1}$-like and $\mathrm{D}_{2}$-like receptors, with some preference for the latter subtypes. A series of new aporphine analogues 5 (aporlogues) were prepared from appropriate aporphine precursors and arylpiperazines using the Click reaction protocol. These compounds displayed good to high affinity at the D3 receptor, low or no affinity at the D1 and D2 receptors. Further assay at the 5-HT1A receptor revealed that some aporlogues also showed high affinity at this receptor with Ki values of 9.68 and $7.59 \mathrm{nM}$, respectively. They were 3.6- and 6.6-fold more potent at the D3 over 5-HT1A receptors. Such D3/5-HT1A dual property of these compounds may be useful in the treatment of several brain disorders (QIAN et al., 2011). The compounds 1-4 and those of the aporlogues-type $\mathbf{5}$ possess an aporphine alkaloid in their structural nucleus, however their substituent are quite different. Nevertheless both hexane extract of $A$. cherimolia, which contents 1-4 and derivativestype 5 showed activity on D2 and 5-HT1 receptors. This result pointed out that, in this case, the presence of an aporphine nucleus is important for the activity.

On the other hand, it has been reported that treatment of PC12 cells with $5-10 \mu \mathrm{M}$ of liriodenine significantly decreased the intracellular dopamine content in a concentration-dependent manner $\left(\mathrm{IC}_{50}\right.$ $8.4 \mu \mathrm{M})$. Liriodenine was not cytotoxic toward PC12 cells at concentrations up to $20 \mu \mathrm{M}$. Tyrosine hydroxylase (TH) and aromatic L-amino acid decarboxylase (AADC) activities were inhibited by $10 \mu \mathrm{M}$ liriodenine to $20-70 \%$ and $10-14 \%$ of control levels at 3-12 h, respectively; TH activity was more influenced than AADC activity. The levels of TH mRNA, intracellular cyclic AMP and basal $\mathrm{Ca} 2+$ concentration were also decreased by $10 \mu \mathrm{M}$ liriodenine. In addition, $10 \mu \mathrm{M}$ liriodenine reduced L-DOPA (20-100 $\mu \mathrm{M})$-induced increases in dopamine content. However, $10 \mu \mathrm{M}$ liriodenine resulted in a protective effect against L-DOPA (50$100 \mu \mathrm{M})$-induced cytotoxicity. These results suggest that liriodenine regulates dopamine biosynthesis by partially reducing $\mathrm{TH}$ activity and $\mathrm{TH}$ gene expression and has protective effects against L-DOPA-induced cytotoxicity in PC12 cells. These results could account for the anti-depressive activity of the hexane extract of $A$. cherimolia. (JIN CM et al., 2007). 


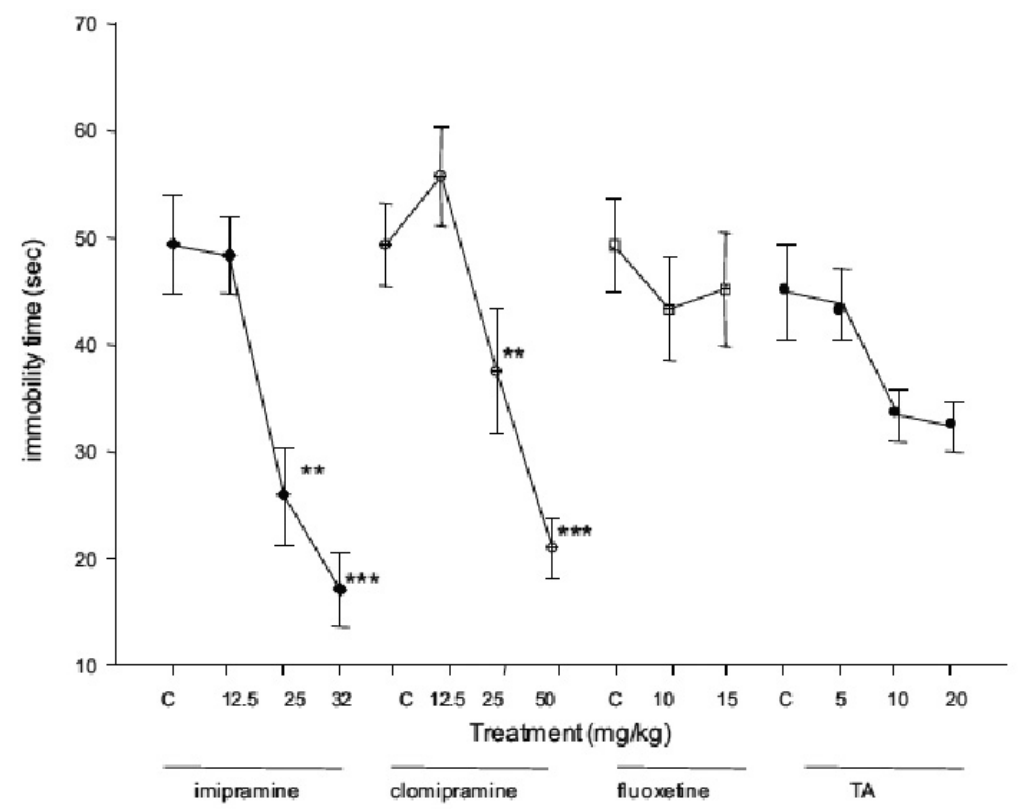

FIGURE 1- Effects of acute administration of an alkaloid extract (TA) from A. cherimolia, imipramine, clomipramine, and fluoxetine on the FST. All results are expressed as the averages $\pm \mathrm{SEM}$ of 16 animals. Comparisons were made using a Kruskal-Wallis one-way analysis of variance on ranks, followed by the Mann-Whitney U-test: ${ }^{*} \mathrm{p}<0.05 ;{ }^{* *} \mathrm{p}<0.01 ; * * * \mathrm{p}<0.001$.

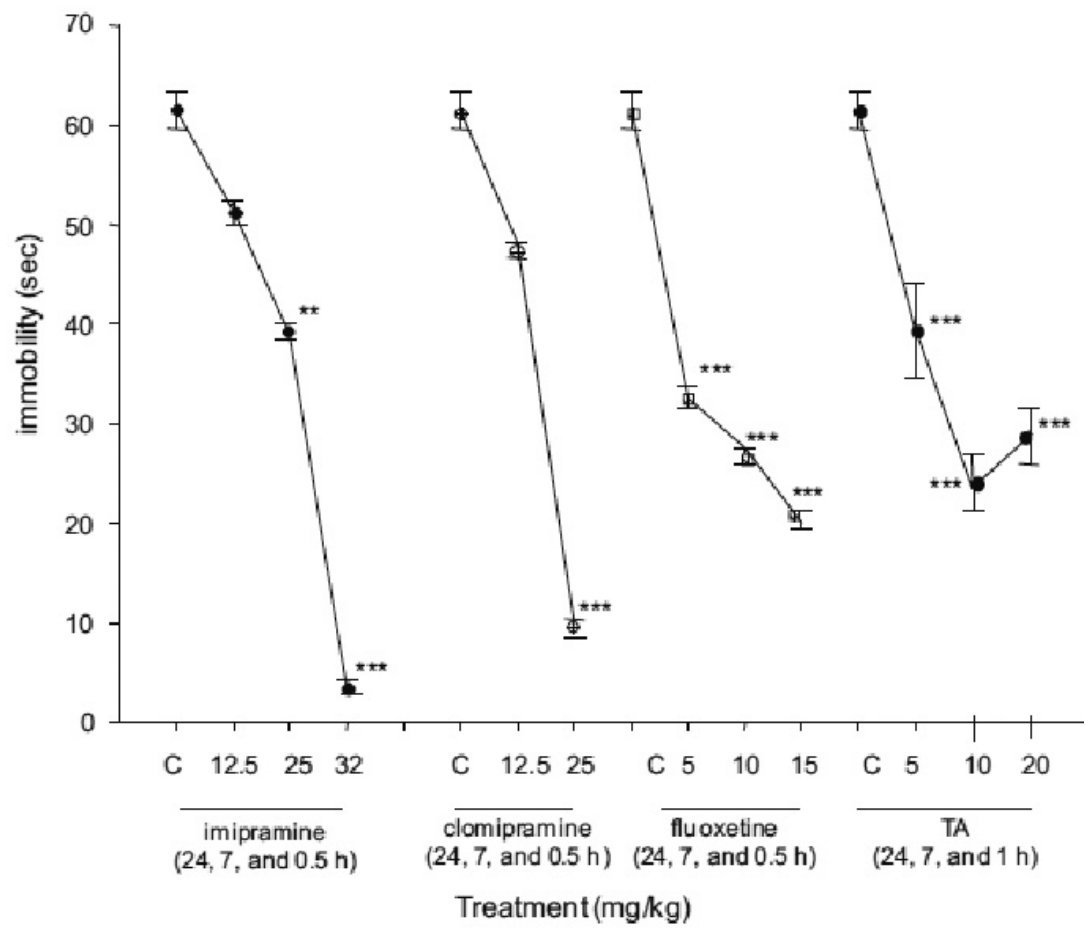

FIGURE 2- Effect of a sub-chronic administration of TA on the forced swimming test. Effect of triple administration of imipramine, fluoxetine, clomipramine, and TA on the forced swimming test (immobility time; seconds). All results are expressed as the averages \pm SEM of 16 animals. Comparisons were made by using a Kruskal-Wallis one way analysis of variance on ranks, followed by Mann-Whitney U-test: *p $<0.05 ; * * p<0.01 ; * *$ p $<0.001$ 
<smiles>[R]C1=C2CCNC3Cc4c(cc([R2])c([R3])c4[R4])C3=C2C(OC)=C1OC</smiles>

$1 \mathrm{R}_{1}=\mathrm{R}_{2}=\mathrm{R}_{3}=\mathrm{R}_{4}=\mathrm{OH}$

$4 \mathrm{R}_{1}=\mathrm{R}_{2}=\mathrm{R}_{3}=\mathrm{R}_{4}=\mathrm{H}$<smiles>c1ccc2c(c1)CC1NCCc3cc4c(c(c3-2)O1)OCO4</smiles>

2<smiles>O=C1c2ccccc2-c2c3c(cc4c2C1NCC4)OCO3</smiles>

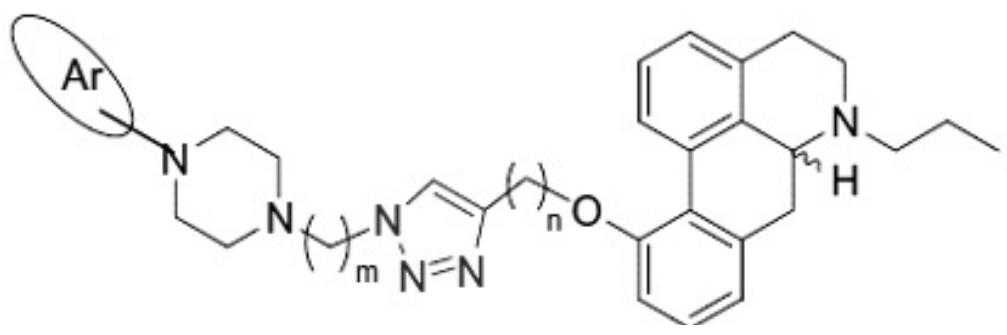

Further studies should be conducted to test the specific participation of each monoamine or other neurotransmitter systems in such actions of TA in the FST.

\section{CONCLUSIONS}

Results showed that TA produces an antidepressant-like action from a generalized increasing monominergic turnover, supporting the use in traditional medicine of Annona cherimolia, and strongly suggest its therapeutic potency as an antidepressant agent

\section{REFERENCES}

BERENGUER, I.; EL AOUAD, N.; ANDUJAR, S.; ROMERO, V.; SUVIRE, F.; FRERET, T.; BERMEJO, A.; IVORRA, M.D.; ENRIZ, R.D.; BOULOUARD, M.; CABEDO, N.; CORTES, D. Tetrahydroisoquinolines as dopaminergic ligands: 1-Butyl-7-chloro-6-hydroxytetrahydroisoquinoline, a new compound with antidepressant-like activity in mice. Bioorganic \& Medicinal Chemistry, Oxford, v.17, n. 4, p.4968-4980, 2009.
BLIER, P.; MONTIGNY, C. Current advances and trends in the treatment of depression. Trends in Pharmacological Sciences, Oxford, v.15, n.7, p.220-226, 1994.

BLIER, P.; WARD, N.M. Is there a role for 5-HT1A agonists in the treatment of depression? Biological Psychiatry, Amsterdam, v.53, n 3, p.193-203, 2003.

CERVO, L.; SAMANIN, R. Potential antidepressant properties of 8-hydroxy-2- (di-n-propylamino) tetralin, a selective serotonin $1 \mathrm{~A}$ receptor agonist. European Journal of Pharmacology, Amsterdam, v.144, n.2, p.223-229, 1987.

CUI YIN, L.; GOU, Y.L.; XIAOXING Y.; LING, Z.; GENGUANG, J.; ZHUANG, X. Antidepressantlike effects of 1-theanine in the forced swim and tail suspension tests in mice. Phytotherapy Research, New York, v.25, n.11, p.1636-1639, 2011. 
GONZALEZ-TRUJANO, M.E.; NAVARRETE, A.; REYES, B.; CEDILLO-PORTUGAL, E.; HONG, E. Anticonvulsant properties and bio-guided isolation of palmitona from leaves of Annona diversifolia. Planta Medica, Stuttgart, v.67, n.2, p.136-141, 2001.

GOUEMO, P.N.; KOUDOGBO, B.; TCHIVOUNDA, P.; AKONO-NGUEMA, C.; ETOUA, M.M. Effects of ethanol extract of Annona muricata on pentylentetazol-induced convulsive seizures in mice. Phytotherapy Research, New York, v.11, n.3, p.243-245, 1997.

GUPTA, M.P. (Ed.). 270 Plantas medicinales iberoamericanas. Santafé de Bogotá: CYTEDSECAB, 1995. p.26-28.

HASRAT J. A.; BRUYNE T. DE; BACKER J.P. DE; VAUQUELIN G.; VLIETINCK A. J. Isoquinoline derivates isolated from the fruit of Annona muricata as 5-HTergic 5-HT1A receptor agonists in rats: unexploited anti-depressive (lead) products. Journal of Pharmacy and Pharmacology, London, v.49, n.11, p.1145-1149, 1997a

HASRAT, J.A.; PIETERS, L.; DE BAKER, J.P.; VAUQUELIN, G.; VLIETINCK, J. Screening of medicinal plants from Suriname for 5-HT1A ligands: bioactive isoquinoline alkaloids from fruit of Annona muricata. Phytomedicine, Jena, v. 4, n.2, p.133-140, $1997 b$.

JIN, CM, LEE, JJ, YANG, YJ, KIM, YM, KIM, YK, RYU, SY, LEE, MK. Liriodenine inhibits dopamine biosynthesis and L-DOPA-induced dopamine content in PC12 Cells. Archives of Pharmacal Research, Seoul Korea, v.30, n.8, p.984-990, 2007.

LEE, J.J.; JIN, C.M.; KIM, Y.K.; RYU, S.Y.; LIM, S.C.; LEE, M.K.. Effects of anonaine on dopamine biosynthesis and L-DOPA-induced cytotoxicity in PC12 cells. Molecules, Basel, v.13, n.2, p.475-487, 2008
LOPEZ-RUBALCAVA, C.; PIÑA-MEDINA, B.; ESTRADA-REYES, R.; HEINZE, G.; MARTINEZVAZQUEZ, M. Anxiolytic actions of the hexane extract from leaves of Annona cherimolia in two paradigms: possible involvement of the GABA/ benzodiazepine receptor complex. Life Science, Oxford, v.78, n.7, p.730-737, 2006.

MARTINEZ-MOTA, L.; ESTRADA-CAMARENA, E.; LOPEZ-RUBALCAVA, C. Indorrenate produces antidepressant-like actions in the rat forced swimming test via 5-HT1A receptors. Psychopharmacology, Heidelberg, v.165, n.1, p.60-66, 2002.

PROTAIS P, ARBAQUI J, BAKKALI E-H Effects of various isoquinoline alkaloids on in vitro 3H-dopamine uptake on striatal synaptosomes. Journal of Natural Products, Washington, v.58, n.10, p.1475-1484, 1995.

QIAN N.Y.; QIAN W.; ZHU L.; ZHENG L.; GAO B.; ZHEN X.; ZHANG, A. Further SAR study on 11-O-substituted aporphine analogues: Identification of highly potent dopamine D3 receptor ligands. Bioorganic \& Medicinal Chemistry, Oxford, v.19, p.1999-2008, 2011.

TORTORIELLO, J.; ROMERO, O. Plants used by Mexican traditional medicine with presumable sedative properties: an ethnobotanical approach. Archives of Medical Research, México, v.23, n.3, p.111-116, 1992. 